\title{
Very Preterm Infant
}

National Cancer Institute

\section{Source}

National Cancer Institute. Very Preterm Infant. NCI Thesaurus. Code C118677.

A newborn infant greater than 28 weeks, 0 days and less than 34 weeks, 0 days. 